\title{
Using PLS-SEM to Examine the Structure of First-year University Students' Mathematics-related Beliefs
}

\author{
Ruixuan $\mathrm{Ji}^{1}$, Xiaoyao Yue $^{2} \&$ Xu Zheng ${ }^{3}$ \\ ${ }^{1}$ College of Arts, Law, and Education, University of Tasmania, Tasmania, Australia \\ ${ }^{2}$ Graduate School of Human Sciences, Assumption University of Thailand, Bangkok, Thailand \\ ${ }^{3}$ School of Foreign study, Shaoguan University, Shaoguan, Guangdong, China \\ Correspondence: Xiaoyao Yue, Graduate School of Human Sciences, Assumption University of Thailand, \\ Bangkok, Thailand. E-mail: sandyyuexiaoyao@gmail.com
}

Received: July 26, 2021

doi:10.5539/hes.v11n4p7
Accepted: September 15, $2021 \quad$ Online Published: September 19, 2021

URL: https://doi.org/10.5539/hes.v11n4p7

\begin{abstract}
Many research indicated that more and more students choose to drop out of mathematics-related subjects during university study, especially in the western context. Besides the difficulty of mathematics content, first-year university students also face issues of the transition period. Identifying the impact of first-year university students' belief factors on their persistence in mathematics study needed further research.

This study served as a pilot study; it structured the framework of first-year university students' mathematics-related beliefs in relation to students' persistence on the further mathematics study. A two-stage approach of using PLS-SEM to assessing the conceptual framework was introduced in detail. The relationships of dimensions of students' epistemological beliefs about mathematics, self-efficacy, self-regulated learning strategies and perceptions about learning environment were assessed. This study provides the feasibility for future follow-up studies to examine mathematics-related beliefs and intentions to continue learning among university students on a larger scale.
\end{abstract}

Keywords: beliefs, relationships, persistence on mathematics, PLS-SEM, model specification

\section{Introduction}

Research related to students' mathematical related beliefs is receiving increasing attention. Realising learners' beliefs is important to understand their thought processes, learning approaches, and changes of attitude (Schommer, 1998). Students, who have just finished secondary-level studies, often encounter many difficulties as they can adapt to university study. Rach and Heinze (2017) pointed out that the dropout rate of undergraduate students in mathematics has been increasing, and this phenomenon is prevalent in western countries. With the general acceptance of this perception, seeking what affects students' persistence in mathematics learning is significant and how to decrease the dropout rate are needed to be researched.

D'souza and Wood (2003) pointed out that “Tertiary students' experiences during their first year of study appear to be crucial to personal adjustment and academic" (p. 1). They suggested that the degree of student adaptation during the transitional learning process determines whether they will continue, postpone or dropout of mathematics learning. Therefore, identifying the effect and relationship among different types of beliefs is the foundation for removing obstacles in learning mathematics and forming effective learning strategies.

Students' conceptions of mathematics and their attitudes towards mathematics influence their higher education chances and future decision.

Students' conceptions of mathematics and their attitudes towards mathematics influence their higher education chances and future decision. Both affective factors and the relationship between affective and cognitive factors are undoubtedly important to studying mathematical tertiary transition problems (Di Martino \& Gregorio, 2019). It is significant to identify the influence of first-year University students' beliefs on mathematics to persistence on mathematics. As mentioned above, the significance and value of investigating university students' mathematics-related beliefs have been demonstrated. Op't Eynde et al. (2002) noted that belief-related variables usually are studied individually, and it is necessary to explore a systematic combination of a range of students' 
related beliefs together.

\section{Mathematics Learning during Tertiary Transition}

Hoyles et al. (2001) argued that many of the changes to make mathematics more widely applicable might have made the transition more problematic. University students, including some high achievers, are often troubled because of the difficulties of mathematics learning at tertiary level study (Liston \& O'Donoghue, 2007). The transition difficulties have been considered unavoidable. Tall (2002) mentioned that transition occurred mainly to encounter with new content in advanced mathematics learning. There is an apparent cognitive discontinuity between two different levels of study. During the period of transition from one stage to another (e.g., secondary-tertiary transition), students' academic achievement shows an evident decline (Rice, 2001). "New knowledge often contradicts the old, and effective learning requires strategies to deal with conflicts. Sometimes the conflicting pieces of knowledge can be reconciled, sometimes one or the other must be abandoned, and sometimes the two can both be 'kept around' if safely maintained in separate compartments."(Tall, 2002, p. 9). This problem refers to the situation in which the new knowledge is not well accommodated in one's process of cognitive development.

Tall (2002) also addressed other difficulties that arise when studying advanced mathematics. The advanced mathematics knowledge is too abstract for many students-learning new knowledge by rote results in difficulty integrating it with previous experience.

Clark and Lovric (2008) suggested a three-stage process (separation, liminal, and incorporation) to describe the transition from secondary school to university study. They considered the secondary-tertiary transition process followed the modern-day rite of passage, which is described as one's perception has been abruptly interrupted, changed, and distorted.

Gueudet (2008) addressed that even students can sense that the difficulties clearly existed during the transition period. She suggested that first-year university students usually solve mathematical problems based on their previous experience, while mathematicians generally display more flexibility in thinking and reasoning. She also expressed the necessity of figuring out the causes of difficulties during the mathematics learning process. She believed that identifying those difficulties can help develop more appropriate learning behaviour and concepts.

\subsection{Effect of Mathematics-related Beliefs to Mathematics Learning Process}

Wood et al. (2012) addressed that students' conceptions about mathematics can profoundly affect their learning. Di Martino and Gregorio (2019) pointed out that the cognitive aspects of university mathematics have been well researched in recent years; the research of affective elements is inadequate. This phenomenon is described as "a critical issue" that many high achievers in secondary school may not adapt well when they enter university. Many kinds of research have investigated many aspects of students' beliefs about mathematics at different levels of study; the majority of investigations are focused on the secondary level. Mason (2003) researched to investigate Italian high school students' belief about mathematics and problem-solving ability with their academic achievement. Op't Eynde and De Corte (2003) considered that students' epistemological beliefs about mathematics constituted a system to affect their learning behaviour and attitudes toward mathematics. Research on students' epistemic beliefs has been concerned with specific subject-matter fields, including mathematics. Several studies have indicated the relationship between students' epistemological beliefs and their state of learning advanced mathematics in university (Krupnik et al., 2018). Dawkins and Weber (2017) considered that a reason for which some students struggle with mathematics learning is that they do not form appropriate epistemological beliefs to support them to learn advanced mathematics content. According to Schoenfeld (1985), beliefs in mathematics education can be categorised as beliefs about the nature of mathematics, mathematics learning, and problem-solving. The student's mathematical beliefs can be concluded as being on a continuum from invalid to practical. The mathematics beliefs of students refer to the mathematics epistemic belief system that affects their mathematics learning process and results (Muis, 2004). ifferent types of students' beliefs have been studied separately. Only a few scholars have researched those beliefs together in an integrative way (Op't Eynde et al., 2006).

Callejo and Vila (2009) analysed two mathematics belief systems of high-achieving students. They found that students' belief systems with good grades had a positive effect on their mathematical problem-solving. Stockton (2010) conducted in-depth research on the relationship between mathematics beliefs and SRL (self-regulated learning processes) in college students' advanced mathematics-learning process. Students' epistemic mathematics beliefs, problem-solving strategies, and self-regulation are closely related.

Liston and O’Donoghue (2007) pointed out that factors associated with self-concept, self-efficacy, and 
confidence significantly influence the process of learning mathematics. They also suggested it is necessary to pay attention to the development of attitudes during mathematics learning. Davis Kean et al. (2008) found that, as students grow older, the relationship between their self-efficacy and learning behaviours have become close. This trend was observed both for male and female students.

The perceived learning environment for students consists typically of students' perspectives of their teachers, peers, learning activities, and student engagement in the classroom. The teacher's learning assistance has a guiding role for students to learn mathematics (Khine et al., 2018). Fraser (1991) showed that the classroom environment affected students' performance and attitudes toward mathematics. The learning environment is one of the critical constituents of students' learning. According to Khine et al. (2018), the characteristics of the classroom learning environment are significantly influential on students' attitudes towards specific subjects learning and cognitive outcomes. The influence of the learning environment is one of the leading causes of difficulty in mathematics learning (Quilter \& Harper, 1988).

\subsection{The Use of SEM}

We consider using structural equation modelling to assess the relationships among variables. Literature indicated that Structural Equation Modelling (SEM) has been a popular technique to explore relationships among multiple variables (Bentler \& Yuan, 1999).

Hair et al. (2019) mentioned that covariance-based structural equation modelling (CB-SEM) was viral to explore the interrelationships among variables. According to previous works of literature, CB-SEM has been the predominant approach, yet PLS-SEM is increasingly used in various disciplines (Hair et al., 2014).

Hair et al. (2011, p. 144) recommend:

- 'If the goal is predicting key target constructs or identifying key 'driver' constructs, select PLS-SEM.

- If the goal is theory testing, theory confirmation, or comparison of alternative theories, select CB-SEM.

- If the research is exploratory or an extension of an existing structural theory, select PLS-SEM."

Following this recommendation, CB-SEM would be appropriate for this study. However, many researchers designed consistent PLS estimations of common factor models to imitate CB-SEM (Bentler \& Huang, 2014; Dijkstra, 2014; Dijkstra \& Henseler, 2015), which addressed that PLS-SEM can be used to study structure. Moreover, Goodhue et al. (2012, p. 981) mentioned that:

"There is a pervasive belief in the Management Information Systems (MIS) research community that for small sizes or data with non-normal distributions, partial least squares (PLS) has advantages that make it more appropriate than other statistical estimation techniques such as regression or covariance-based structural equation modelling (CB-SEM) with LISREL, Mplus, etc."

Several reasons of why researchers should select PLS-SEM between CB-SEM and PLS-SEM were concluded by Hair et al. (2019, p. 5):

- When the analysis is concerned with testing a theoretical framework from a prediction perspective;

- When the structural model is complex and includes many constructs, indicators and/or model relationships;

- When the research objective is to better understand increasing complexity by exploring theoretical extensions of established theories (exploratory research for theory development);

- When the path model includes one or more formatively measured constructs;

- When the research consists of financial ratios or similar types of data artifacts;

- When the research is based on secondary/archival data, which may lack a comprehensive substantiation on the grounds of measurement theory;

- When a small population restricts the sample size (e.g. business-to-business research); but PLS-SEM also works very with large sample size;

- When distribution issues are a concern, such as lack of normality; and

- When research requires latent variable scores for follow-up analyses.

Hair et al. (2019) also mentioned that a higher degree of statistical power could be perceived from using the PLS-SEM approach rather than CB-SEM (Hair et al., 2017; Reinartz et al., 2009). A higher degree of statistical power means it is more likely to identify significant relationships among variables when the relations have really existed. Besides, another advantage of using PLS-SEM is that it does not need the data set to follow a normal distribution. The data distribution reason for choosing PLS-SEM is not sufficient because the non-normal data could affect the results in some situations (Sarstedt et al., 2017). However, considering the reasons listed above, the PLS-SEM is considered the suitable approach for this study. 


\subsection{The Aim of Study}

This is a pilot study; one of the study aims is to examine the reliability of the questionnaire and the data analysis process for future research. In addition, the findings of this study hope to assist first-year students who choose mathematics-related subjects to understand the importance of their mathematics-related beliefs to tertiary mathematics study, to complete transition and reduce difficulties they experience in tertiary mathematics learning.

\subsection{Theoretical Foundation}

In this study, the relationships among five types of students' mathematics-related beliefs (epistemological dimensions, self-efficacy, self-regulated strategies, psychosocial environment about classroom, and persistence on mathematics) need to be measured. In addition, these variables' influences on the trend of students' persistence in mathematics learning also need to be verified. Theories supported this study included:

- The reciprocal determinism suggested by Bandura (1986) provide a significant theoretical framework for this study to explore the hypothetical path relationship among these variables.

- Framework of students' mathematics-related belief systems developed by Op't Eynde et al. (2002) introduced the different relevant belief categories about mathematics and the structure of students' mathematics-related belief systems.

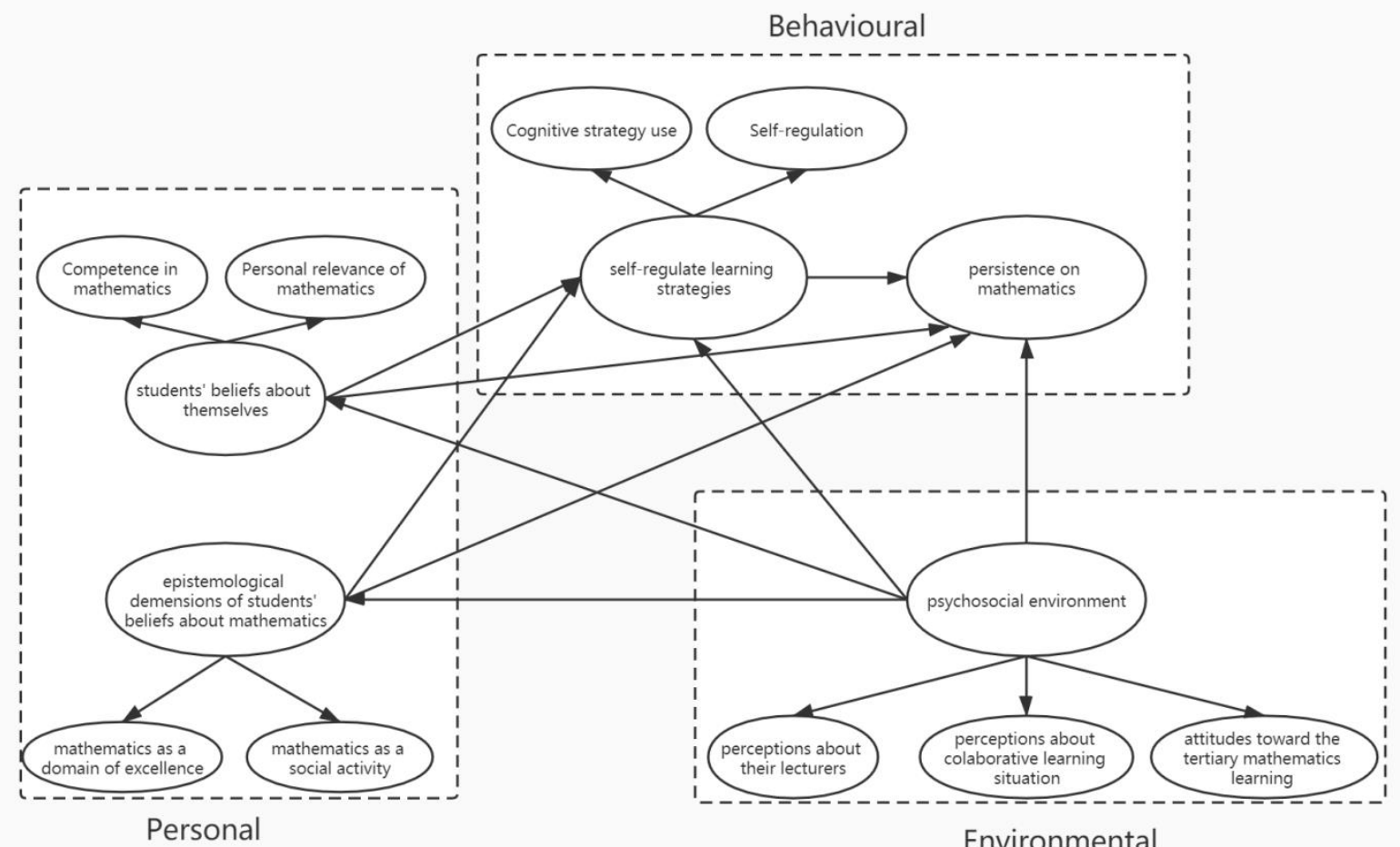

Figure 1. Conceptual framework

Bandura (1986) stressed that only environmental factors cannot fully determine people's learning behaviour. In addition to environmental factors, individuals' personal opinions about their characteristics and reaction behaviour are also crucial for making decisive behaviour. According to Op't Eynde et al. (2002), the framework of students' mathematics-related beliefs system is constituted by their beliefs about themselves, mathematics education, and contexts. Synthesising the content of the structure of beliefs, the function of the specific context (such as the classroom), to a certain extent, promotes students to put their prior knowledge and beliefs into the new learning environment so that students' concepts about the subject can be developed. Students' beliefs about mathematics education are influenced by the context and students' psychological needs, desires, goals etc. Beliefs about the self-associate with mathematics refer to the affective domains to mathematic study based on three motivational constructs (Pintrich, 1989): expectancy, value and affect.

The hypotheses suggested for this study were based mainly on Bandura's theory of reciprocal determinism. 
Pajares and Usher (2008) quoted Johnny's example to explain how personal, behavioural, and environmental factors mutually interacting forces can influence each other. The example addressed that how the environmental factors, such as his teacher's personality and verbal persuasions, and modelling from peers, influenced his personal factors (his attitude and confidence standard on math study). Such influences resulted in Johnny's behavioural changes, as he persevered in mathematics, became more engaged in class, actively worked with peers, and looked for challenges on his own initiative. It worked in a chain that included Johnny's new attitudes and beliefs about mathematics learning, affected subsequent environmental factors (his teacher feels encouraged and seeks new challenges for him) and personal factors, for example, his new-found success improved his self-regulated practices, his greater motivation toward mathematics study, which led to his satisfaction in mathematics rising. Such influences to further behavioural changes, for instance he continued learning mathematics and even joined the math club. According to the logic of this example, within the constructs described in each of the three categories of the conceptual framework proposed in Figure 2, the following relationships are hypothesised:

1) Psychosocial environment effect (Fraser, 2019; Wong et al., 2016; Wu, 2018):

(H1) Psychosocial environment has a positive effect on students' epistemological dimensions of students 'beliefs about mathematics;

(H2) Psychosocial environment has a positive effect on students' self-regulated learning strategies;

(H3) Psychosocial environment has a positive effect on students' beliefs about themselves;

(H4) Psychosocial environment directly affects students' persistence on mathematics;

2) Personal factors effect (Kizilgunes et al., 2009; Phan, 2008; Schunk \& Usher, 2011; Wu, 2018):

(H5) Students' epistemological dimensions of students 'beliefs has a positive effect on students' self-regulated learning strategies;

(H6) Students' epistemological dimensions of students 'beliefs directly affects students' persistence on mathematics;

(H7) Students' beliefs about themselves has a positive effect on self-regulated learning strategies;

(H8) Students' beliefs about themselves has a positive effect on persistence on mathematics;

3) Behavioural effect (Rosário et al., 2013; Zimmerman \& Schunk, 2011):

(H9) Self-regulated learning strategies has a positive effect on persistence on mathematics.

\section{Methodology}

The survey conducted for this study is to clarify the relationships among university students' mathematics-related beliefs, and to explore the influences of students' mathematics-related beliefs on their persistence with mathematics learning. A demographic section had been provided to students to ask them to supply their demographic data before completing the questionnaire. The demographics section included students' prior mathematics learning and reasons for taking mathematics at first year university level, as their pathways and motivation for study may well be impacted by, and/or affect their beliefS. The initial survey selected 55 items for the investigation.

Many researchers recommend that the outer loadings should be more than 0.70 (Hair et al., 2019). Given this study is of an exploratory nature, the indicators with the outer loadings from $0.4-0.7$ may be also retained (Hair et al., 2016; Hair et al., 2014). In order to increase the convergent validity of the measurement models, the items with outer loadings less than 0.5 were considered non-significant and deleted, because indicators with outer loadings below 0.4 should always be eliminated from the construct (Hair et al., 2011). At last, $\mathbf{4 4}$ items were left and used to examine epistemological dimension of students' beliefs about mathematics education, students' beliefs about themselves, self-regulated learning strategies, and perceptions of learning environment are selected from established instruments.

Table 1. Sources of items selected in the survey

\begin{tabular}{ll}
\hline Sources & Number of selected items \\
\hline Mathematics-related beliefs questionnaire (Op't Eynde et al., 2006) & 10 \\
Mathematics Self-efficacy Questionnaire (May \& Glynn, 2008) & 9 \\
The Motivated Strategies for Learning Questionnaire (Pintrich \& De Groot, 1990) & 10 \\
What Is Happening in This Classroom (Fraser, 1998) & 15 \\
\hline
\end{tabular}




\subsection{Participants}

The participants of this study are Australian university students who need to learn mathematics during their undergraduate studies, including first, second, and third-year students. The responses from first-year university students who enrolled in mathematics course/unit study in the middle of semester 12019 from two Australian universities. Students were mainly enrolled in one mathematics course at a time; only a small number of students took one or two additional math courses in this semester. According to the overviews of these courses, the contents are all about fundamental mathematics, very similar to what students had learnt in secondary school.

\subsection{Data Analysis}

In order to analysis the quantitative data collected by the survey. We applied Partial Least Squares Structural Equation Modelling (PLS-SEM) to deal with the data collected. The Structural Equation Modelling (SEM) has been a popular technique to explore relationships among multiple variables (Bentler \& Yuan, 1999). Hair et al. (2011) described SEM as "a 'quasi-standard' in marketing and management research when they need to identify the cause-effect relations among latent constructs. PLS-SEM is commonly used in exploratory research. According to Hair et al. (2016), PLS-SEM is a non-parametric method, no identification issues while dealing with small sample size, and suitable to handle models with complex structure. Considering those advantage characteristics, we implement PLS Algorithm calculation in SmartPLS 3 software.

\section{Results}

The proposed framework has double layer of constructs. The first-order constructs is reflective and the second-order model is formative. According to Hair et al. (2016), when assessing reflective measurement model, Outer loadings, Composite Reliability, Cronbach's Alpha, Average Variance Extracted (AVE), and Discriminant Validity.

After run PLS-Algorithm, all outer loadings of the indicators can be found in Final Results report. All outer loadings of the first-order constructs are above 0.5. The outer loadings indicated the relationships between the reflective latent variables and their indicators. The Composite Reliability and Validity is under Quality Criteria in the results report.

Table 2. First-order variables' construct reliability and validity

\begin{tabular}{lllll}
\hline & & Cronbach's Alpha & Composite Reliability & AVE \\
\hline $\begin{array}{l}\text { Self-regulated } \\
\text { learning } \\
\text { strategies }\end{array}$ & $\begin{array}{l}\text { Self-regulation } \\
\text { Cognitive strategy use }\end{array}$ & 0.7 & 0.80 & 0.45 \\
$\begin{array}{l}\text { Psychosocial } \\
\text { learning } \\
\text { environment }\end{array}$ & $\begin{array}{l}\text { Perceptions about their lecturers } \\
\text { Perceptions about collaborative }\end{array}$ & 0.68 & 0.80 & 0.51 \\
& $\begin{array}{l}\text { learning situation } \\
\text { Attitudes toward tertiary }\end{array}$ & 0.80 & 0.92 & 0.69 \\
$\begin{array}{l}\text { mathematics learning } \\
\text { Students' beliefs }\end{array}$ & Personal relevance of mathematics & 0.77 & 0.87 & 0.63 \\
$\begin{array}{l}\text { Epout themselves } \\
\text { dimensions }\end{array}$ & $\begin{array}{l}\text { Competence in mathematics } \\
\text { Mathematics as a social activity }\end{array}$ & 0.78 & 0.84 & 0.48 \\
& Mathematics as a domain of excellence & 0.73 & 0.88 & 0.55 \\
& & & 0.87 & 0.70 \\
& & 0.83 & 0.50 \\
\hline
\end{tabular}

As can be seen, the Cronbach's alpha values for the first-order constructs are above the 0.70 thresholds, except Cognitive Strategy part (0.68), which did not reach 0.70 but was very close to. According to Hair Jr et al. (2016), Composite Reliability is a more conservative measure of internal consistency reliability as Cronbach's alpha. It varies between 0 and 1, the higher values indicating higher reliability. All values of CR showed in table 2 are above 0.8 (the highest is perceptions about their lecturers 0.92, the lowest is 0.80), which can be regarded as satisfactory. AVE is calculated to assess convergent validity. The values of AVE typically suggest being higher than 0.5, which means the construct explains more than half of the variance of their indicators. In table 2, the value of AVE in Mathematics as a domain of excellence, Attitudes toward tertiary mathematics learning, and Self-regulation did not meet the value of 0.5. However, this still can be accepted, as Fornell and Larcker (1981) suggested the convergent validity would still be enough if the composite reliability is higher than 0.6. The AVE is lower than 0.5 . 
Table 3. Discriminant Validity (Heterotrait-Monotrait Ratio)

\begin{tabular}{|c|c|c|c|c|c|c|c|c|}
\hline & $\begin{array}{l}\text { Attitudes toward } \\
\text { tertiary } \\
\text { mathematics } \\
\text { learning }\end{array}$ & $\begin{array}{l}\text { Cognitive } \\
\text { strategy } \\
\text { use }\end{array}$ & $\begin{array}{l}\text { Competence } \\
\text { in } \\
\text { mathematics }\end{array}$ & $\begin{array}{l}\text { Mathematics as a } \\
\text { domain of } \\
\text { excellence }\end{array}$ & $\begin{array}{l}\text { Mathematics } \\
\text { as } \\
\text { a social } \\
\text { activity }\end{array}$ & $\begin{array}{l}\text { Personal } \\
\text { relevance } \\
\text { of mathematics }\end{array}$ & $\begin{array}{l}\text { Perceptions about } \\
\text { colaborative } \\
\text { learning } \\
\text { situation }\end{array}$ & $\begin{array}{l}\text { Perceptions } \\
\text { about } \\
\text { their lecturers }\end{array}$ \\
\hline $\begin{array}{l}\text { Cognitive } \\
\text { strategy use }\end{array}$ & 0.6 & & & & & & & \\
\hline $\begin{array}{l}\text { Competence } \\
\text { in mathematics }\end{array}$ & 0.80 & 0.88 & & & & & & \\
\hline $\begin{array}{l}\text { Mathematics as a } \\
\text { domain of } \\
\text { excellence }\end{array}$ & 0.39 & 0.63 & 0.43 & & & & & \\
\hline $\begin{array}{l}\text { Mathematics as a } \\
\text { social activity }\end{array}$ & 0.35 & 0.59 & 0.28 & 0.9 & & & & \\
\hline $\begin{array}{l}\text { Personal relevance } \\
\text { of mathematics }\end{array}$ & 0.62 & 0.61 & 0.84 & 0.66 & 0.62 & & & \\
\hline $\begin{array}{l}\text { Perceptions } \\
\text { about collaborative } \\
\text { learning situation }\end{array}$ & 0.26 & 0.31 & 0.15 & 0.25 & 0.31 & 0.20 & & \\
\hline $\begin{array}{l}\text { Perceptions about } \\
\text { their } \\
\text { lecturers }\end{array}$ & 0.20 & 0.2 & 0.34 & 0.28 & 0.25 & 0.29 & 0.30 & \\
\hline Self-regulation & 0.41 & 0.61 & 0.47 & 0.68 & 0.56 & 0.50 & 0.18 & 0.26 \\
\hline
\end{tabular}

The Heterotrait-Monotrait Ratio (HTMT) has been considered as a frequently used criterion to assess Discriminant Validity. Hair et al. (2016) suggested using 0.85 as a conservative threshold. Table 3 shows the HTMT values for all the pairs of constructs. The value of HTMT for two dimensions of epistemological beliefs about mathematics is 0.9 , which is considered very similar, as well as the values for self-regulated learning strategies (0.88). The rest HTMT values are all lower than the threshold value of 0.85 .

From these assessments, most of the evaluation of model criteria has been met, and the first-order measurement model showed good reliability and validity.

Then, we extracted the standardised first-order latent variable scores to construct the second-order model (see figure 2).

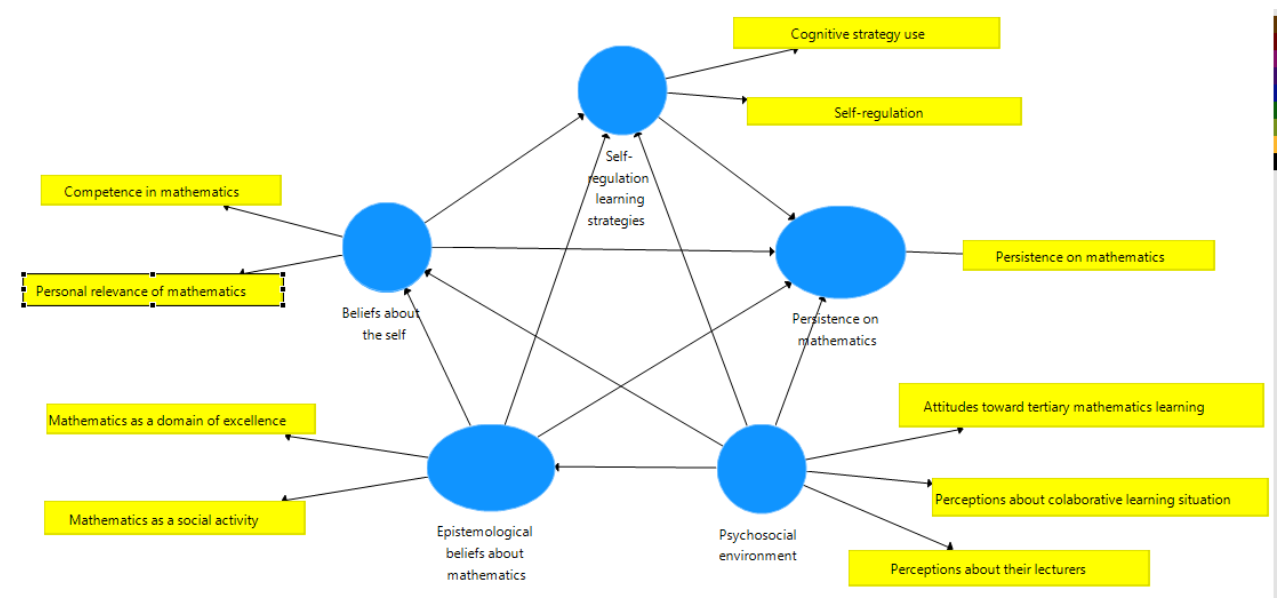

Figure 2. The 2nd-order constructs

Table 4. Second-order variables' construct reliability and validity

\begin{tabular}{llll}
\hline & Cronbach's Alpha & Composite Reliability & AVE \\
\hline Beliefs about the self & 0.818 & 0.916 & 0.846 \\
Epistemological beliefs about mathematics & 0.841 & 0.926 & 0.862 \\
Persistence on mathematics & 1 & 1 & 1 \\
Psychosocial environment & 0.228 & 0.542 & 0.361 \\
Self-regulation learning strategies & 0.617 & 0.838 & 0.721 \\
\hline
\end{tabular}


The construct reliability and validity of the psychosocial environment may not be good because the contribution of the perceptions about collaborative learning situations is too low, with a factor loading of only 0.112 . The Cronbach's alpha value of SRLS is 0.617, it is lower than the threshold value of 0.7. Except for that, the second-order structure indicates acceptable consistency reliability and convergent validity. The persistence on mathematics has only one item, so this constructs' Cronbach's alpha, CR, and AVE are not meaningful.

Shmueli and Koppius (2011) illustrated that the $\mathrm{R}^{2}$ refers to a measure of the model's explanatory power. The range of $R^{2}$ is between $0-1$, the higher the $R^{2}$ value, the higher levels of predictive accuracy. The adjusted $R^{2}$ refers to as the criterion to avoid bias toward complex models. The $\mathrm{R}^{2}$ values of beliefs about the self (0.495), persistence on mathematics (0.462), self-regulated learning strategies $(0.591)$ can be considered moderate, whereas the $\mathrm{R}^{2}$ values of Epistemological beliefs about mathematics (0.115) is rather weak (shown in Table 5).

Table 5. $\mathrm{R}^{2}$ value

\begin{tabular}{lll}
\hline & R Square & R Square Adjusted \\
\hline Beliefs about the self & 0.495 & 0.473 \\
Epistemological beliefs about mathematics & 0.115 & 0.096 \\
Persistence on mathematics & 0.462 & 0.413 \\
Self-regulation learning strategies & 0.591 & 0.564 \\
\hline
\end{tabular}

Within the context of PLS-SEM, the Cohen's $f^{2}$ is given to demonstrate the effect size of the independent variable to the dependent variable. As shown in Table 6, the highlighted $f^{2}$ values indicated that Epistemological beliefs about mathematics has no effect on Persistence on mathematics; Psychosocial environment has no effect on Self-regulation either. The effect of Beliefs about the self (0.08) and Self-regulation (0.058) have on Persistence on mathematics are rather weak.

Table 6. $\mathrm{f}^{2}$ effect sizes

\begin{tabular}{|c|c|c|c|c|c|}
\hline & $\begin{array}{l}\text { Beliefs about } \\
\text { the self }\end{array}$ & $\begin{array}{l}\text { Persistence on } \\
\text { mathematics }\end{array}$ & $\begin{array}{l}\text { Epistemological beliefs } \\
\text { about mathematics }\end{array}$ & $\begin{array}{l}\text { Self-regulation } \\
\text { learning }\end{array}$ & $\begin{array}{l}\text { Psychosocial } \\
\text { environment }\end{array}$ \\
\hline Beliefs about the self & & 0.08 & 0.258 & 0.194 & \\
\hline Epistemological beliefs about mathematics & & 0.003 & & 0.159 & \\
\hline Psychosocial environment & 0.729 & 0.126 & & 0.004 & \\
\hline Persistence on mathematics & & & & & \\
\hline Self-regulation learning & & 0.058 & & & \\
\hline
\end{tabular}

As shown in Table 7, the total effect for the hypothesised relationships range from 0.287 to 0.670 (The impact of psychosocial environment on self-regulated learning strategies was -0.002 , which although significant, should be ignored) are all significant at a 5\% significant level except three hypothetical paths, the effect of Psychosocial environment on Epistemological beliefs about mathematics $(\mathrm{t}=1.953, \mathrm{p}>0.05)$, Epistemological beliefs about mathematics on Persistence on mathematics $(\mathrm{t}=0.441, \mathrm{p}>0.05)$, and Self-regulated learning strategies on Persistence on mathematics ( $\mathrm{t}=1.611, \mathrm{p}>0.05)$.

Table 7. Evaluation of path coefficients and their significance levels

\begin{tabular}{|c|c|c|c|c|c|c|}
\hline \multirow[t]{2}{*}{ hypothesises } & \multirow[t]{2}{*}{ Path coefficients } & \multirow[t]{2}{*}{ Standard Deviation } & \multirow[t]{2}{*}{ T Statistics } & \multirow[t]{2}{*}{ P Values } & \multicolumn{2}{|c|}{ confidence intervals } \\
\hline & & & & & $2.5 \%$ & $97.5 \%$ \\
\hline Beliefs about the self -> Persistence on mathematics & 0.287 & 0.168 & 2.452 & 0.015 & 0.107 & 0.779 \\
\hline Beliefs about the self -> Self-regulation learning strategies & 0.535 & 0.181 & 2.950 & 0.003 & 0.153 & 0.850 \\
\hline Epistemological beliefs about mathematics -> Self-regulation learning strategies & 0.324 & 0.146 & 2.222 & 0.027 & 0.038 & 0.609 \\
\hline Psychosocial environment -> Beliefs about the self & 0.670 & 0.060 & 11.093 & 0.000 & 0.522 & 0.769 \\
\hline Psychosocial environment -> Epistemological beliefs about mathematics & 0.277 & 0.142 & 1.953 & 0.051 & -0.108 & 0.490 \\
\hline Psychosocial environment -> Persistence on mathematics & 0.324 & 0.091 & 6.775 & 0.000 & 0.374 & 0.761 \\
\hline Epistemological beliefs about mathematics -> Persistence on mathematics & -0.024 & 0.118 & 0.441 & 0.659 & -0.210 & 0.268 \\
\hline Psychosocial environment-> Self-regulation learning strategies & -0.002 & 0.113 & 3.934 & 0.000 & 0.117 & 0.625 \\
\hline Self-regulation learning strategies-> Persistence on mathematics & 0.235 & 0.146 & 1.611 & 0.108 & -0.024 & 0.534 \\
\hline
\end{tabular}

\section{Discussion}

Based on the results, our study primarily established the constructs of first-year students' mathematics-related beliefs; the consistent reliability of each construct was considered satisfactory. The composite scale measuring students' mathematics-related beliefs has good reliability; the items in the scale were all extracted from established scales, which means the survey have good validity. 
Students' views about the learning environment directly influence their self-efficacy, epistemological beliefs about mathematics and persistence in mathematics. Their self-efficacy and their epistemological dimensions of beliefs affected students' self-regulated learning strategies. Students' epistemological dimensions of mathematics beliefs had a positive effect on their self-efficacy, and their self-efficacy directly related to their persistence in further mathematics learning. Because of that, this group of students had been at the starting point of their tertiary levels of study; many of the contents of the mathematics courses they enrolled in were similar to what they had learnt in secondary levels of study. That could explain the level of self-efficacy is relatively high for most students. However, as the study goes on, we assume a decline in their self-efficacy because the difficulty level of mathematics content will rise, which will also directly affect students' willingness to continue study mathematics. Only a few students expressed negative emotion because the pace of study was more intensive, more homework, and more dependent on their own. Thus, the support of tutorials and collaboration in mathematics learning needs to be improved.

Given the nature of this study as a pilot, the research focused on the design of a research process suitable for investigating the relationships among students' mathematics-related beliefs. The relationship between these belief variables can be explicitly systematised employing PLS-SEM.

The presentation of the results is not generalisable. With the purpose of conducting generalised results with more specific details, the sample size should be to be expanded. However, this study has already contributed to subsequent studies that can produce generalisable results.

\section{Conclusion}

The results showed that first-year students' mathematics-related beliefs are interrelated, which fit the theoretical foundation indicated. For those first-year students who just started tertiary mathematics learning, their psychosocial environment had a moderately weaker impact on their epistemological beliefs about mathematics. In comparison, the psychosocial environment had a more substantial influence on students' beliefs about themselves; their beliefs about the 'self' mainly refers to their self-efficacy. However, the psychosocial environment showed no effects on their persistence of learning mathematics in their future studies and self-regulated learning strategies. Students' epistemological beliefs about mathematics showed no direct relation to the persistence of mathematics learning. However, their epistemological beliefs positively affected their beliefs about the self and their self-regulation learning strategies. Students' beliefs about the self positively affect their self-regulated learning strategies and their persistence in mathematics learning. However, their self-regulation learning strategies did not affect their persistence in mathematics.

The study also has limitations. Firstly, the sample size is a bit too small, despite that PLS-SEM is suitable for analysing a small sample size because the structural framework is complex. The results may be different when the sample size gets larger. Secondly, deep reasons why students would continue to learn the subjects have not been investigated. Whether they would give up or continue study could be different while simply asking their satisfaction with the current learning situation or whether they wish to continue, which may not reflect students' intention to continue mathematics learning accurately. We only conducted a single item to evaluate students' intention to persist in further mathematics learning; in future research, it would be appropriate to change this to a multi-item measure to obtain more reliable conclusions.

Moreover, this study does not include students' academic achievement into consideration. Hence, future studies are suggested to enlarge the sample size and add up interviews to seek deeper reasons for students' persistence in mathematics. In addition, whether students' beliefs would change when students moved to study, still awaiting further investigation. Moreover, the results only indicated a direct effect among those five dimensions of beliefs; the mediation effect needs further exploration in the future.

In the end, some of the evaluation criteria did not show satisfactory results. The main reason should be that the sample size is too small, and the framework structure is a bit complex. We did not consider the sample size at this stage, since the purpose of this study is mainly to provide feasibility for subsequent studies. The results derived from this study are not generalisable. Hence, we did not analyse all the hypothetical relationships in the framework in a fine-grained way. We assume better results coming when we get more responses.

\section{References}

Bandura, A. (1986). Social foundations of thought and action. Englewood Cliffs, NJ.

Bentler, P. M., \& Huang, W. (2014). On components, latent variables, PLS and simple methods: Reactions to Rigdon's rethinking of PLS. Long Range Planning, 47(3), 138-145.

https://doi.org/10.1016/j.lrp.2014.02.005 
Bentler, P. M., \& Yuan, K.-H. (1999). Structural equation modeling with small samples: Test statistics. Multivariate behavioral research, 34(2), 181-197. https://doi.org/10.1207/S15327906Mb340203

Clark, M., \& Lovric, M. (2008). Suggestion for a theoretical model for secondary-tertiary transition in mathematics. Mathematics Education Research Journal, 20(2), 25-37. https://doi.org/10.1007/BF03217475

D'souza, S. M., \& Wood, L. N. (2003). Tertiary students' views about group work in mathematics. Retrieved February, 9, 2009.

Davis Kean, P. E., Huesmann, L. R., Jager, J., Collins, W. A., Bates, J. E., \& Lansford, J. E. (2008). Changes in the relation of self-efficacy beliefs and behaviors across development. Child Development, 79(5), 1257-1269. https://doi.org/10.1111/j.1467-8624.2008.01187.x

Dawkins, P. C., \& Weber, K. (2017). Values and norms of proof for mathematicians and students. Educational Studies in Mathematics, 95(2), 123-142. https://doi.org/10.1007/s10649-016-9740-5

Di Martino, P., \& Gregorio, F. (2019). The mathematical crisis in secondary-tertiary transition. International Journal of Science and Mathematics Education, 17(4), 825-843. https://doi.org/10.1007/s10763-018-9894-y

Dijkstra, T. K. (2014). PLS'Janus face-response to professor Rigdon's 'rethinking partial least squares modeling: in praise of simple methods'. Long Range Planning, 47(3), 146-153. https://doi.org/10.1016/j.lrp.2014.02.004

Dijkstra, T. K., \& Henseler, J. (2015). Consistent partial least squares path modeling. MIS quarterly, 39(2). https://doi.org/10.25300/MISQ/2015/39.2.02

Fornell, C., \& Larcker, D. F. (1981). Evaluating structural equation models with unobservable variables and measurement error. Journal of marketing research, 18(1), 39-50. https://doi.org/10.1177/002224378101800104

Fraser, B. J. (1991). Two decades of classroom environment research.

Fraser, B. J. (1998). Classroom environment instruments: Development, validity and applications. Learning environments research, 1(1), 7-34. https://doi.org/10.1023/A:1009932514731

Fraser, B. J., \& Skordi, P. (2019). 7 THE ASSESSMENT OF THE PSYCHOSOCIAL LEARNING ENVIRONMENT OF UNIVERSITY STATISTICS CLASSROOMS. The Translational Design of Universities: An Evidence-Based Approach. p. 131. https://doi.org/10.1163/9789004391598_009

Goodhue, D. L., Lewis, W., \& Thompson, R. (2012). Does PLS have advantages for small sample size or non-normal data? MIS quarterly, 981-1001. https://doi.org/10.2307/41703490

Gueudet, G. (2008). Investigating the secondary-tertiary transition. Educational Studies in Mathematics, 67(3), 237-254. https://doi.org/10.1007/s10649-007-9100-6

Hair, Hult, G. T. M., Ringle, C., \& Sarstedt, M. (2016). A primer on partial least squares structural equation modeling (PLS-SEM). Sage publications. https://doi.org/10.15358/9783800653614

Hair, Hult, G. T. M., Ringle, C. M., Sarstedt, M., \& Thiele, K. O. (2017). Mirror, mirror on the wall: a comparative evaluation of composite-based structural equation modeling methods. Journal of the Academy of Marketing Science, 45(5), 616-632. https://doi.org/10.1007/s11747-017-0517-x

Hair, Ringle, C. M., \& Sarstedt, M. (2011). PLS-SEM: Indeed a silver bullet. Journal of Marketing theory and Practice, 19(2), 139-152. https://doi.org/10.2753/MTP1069-6679190202

Hair, Risher, J. J., Sarstedt, M., \& Ringle, C. M. (2019). When to use and how to report the results of PLS-SEM. European Business Review, 31(1), 2-24. https://doi.org/10.1108/EBR-11-2018-0203

Hair, Sarstedt, M., Hopkins, L., \& Kuppelwieser, V. (2014). Partial least squares structural equation modeling (PLS-SEM) An emerging tool in business research. European Business Review, 26(2), 106-121. https://doi.org/10.1108/EBR-10-2013-0128

Hair Jr, J. F., Hult, G. T. M., Ringle, C., \& Sarstedt, M. (2016). A primer on partial least squares structural equation modeling (PLS-SEM). Sage publications. https://doi.org/10.15358/9783800653614

Hoyles, C., Newman, K., \& Noss, R. (2001). Changing patterns of transition from school to university mathematics. International Journal of Mathematical Education in Science and Technology, 32(6), 829-845. https://doi.org/10.1080/00207390110067635

Khine, M. S., Fraser, B. J., Afari, E., Oo, Z., \& Kyaw, T. T. (2018). Students' perceptions of the learning 
environment in tertiary science classrooms in Myanmar. Learning environments research, 21(1), $135-152$. https://doi.org/10.1007/s10984-017-9250-0

Kizilgunes, B., Tekkaya, C., \& Sungur, S. (2009). Modeling the relations among students' epistemological beliefs, motivation, learning approach, and achievement. The Journal of Educational Research, 102(4), 243-256. https://doi.org/10.3200/JOER.102.4.243-256

Krupnik, V., Fukawa-Connelly, T., \& Weber, K. (2018). Students' epistemological frames and their interpretation of lectures in advanced mathematics. The Journal of Mathematical Behavior, 49, 174-183. https://doi.org/10.1016/j.jmathb.2017.12.001

Liston, M., \& O’Donoghue, J. (2007). The Transition from Secondary School Mathematics to University Mathematics. In Obtido em.

Mason, L. (2003). High school students' beliefs about maths, mathematical problem solving, and their achievement in maths: A cross-sectional study. Educational psychology, 23(1), 73-85. https://doi.org/10.1080/01443410303216

May, D., \& Glynn, S. (2008). A mathematics self-efficacy questionnaire for college students. Conference on Research in Undergraduate Mathematics Education, Mathematics Association of America, San Diego.

Muis, K. R. (2004). Personal epistemology and mathematics: A critical review and synthesis of research. Review of educational research, 74(3), 317-377. https://doi.org/10.3102/00346543074003317

Op't Eynde, P., \& De Corte, E. (2003). Students' Mathematics-Related Belief Systems: Design and Analysis of a Questionnaire.

Op't Eynde, P., De Corte, E., \& Verschaffel, L. (2002). Framing students' mathematics-related beliefs. In G. C. Leder, E. Pehkonen \& G. Törner (Eds.), Beliefs: A hidden variable in mathematics education? (pp. 13-37). Springer. https://doi.org/10.1007/0-306-47958-3_2

Op't Eynde, P., De Corte, E., \& Verschaffel, L. (2006). Epistemic dimensions of students' mathematics-related belief systems. International Journal of Educational Research, 45(1-2), 57-70. https://doi.org/10.1016/j.ijer.2006.08.004

Pajares, F., \& Usher, E. L. (2008). Self-efficacy, motivation, and achievement in school from the perspective of reciprocal determinism. Advances in motivation and achievement, 15, 391-423. https://doi.org/10.1016/S0749-7423(08)15012-9

Phan, H. P. (2008). Predicting change in epistemological beliefs, reflective thinking and learning styles: A longitudinal study. British Journal of Educational Psychology, 78(1), 75-93. https://doi.org/10.1348/000709907X204354

Pintrich, P. R. (1989). The dynamic interplay of student motivation and cognition in the college classroom. Advances in motivation and achievement, 6, 117-160.

Pintrich, P. R., \& De Groot, E. V. (1990). Motivational and self-regulated learning components of classroom academic performance. Journal of Educational Psychology, 82(1), 33. https://doi.org/10.1037/0022-0663.82.1.33

Rach, S., \& Heinze, A. (2017). The transition from school to university in mathematics: Which influence do school-related variables have? International Journal of Science and Mathematics Education, 15(7), 1343-1363. https://doi.org/10.1007/s10763-016-9744-8

Reinartz, W., Haenlein, M., \& Henseler, J. (2009). An empirical comparison of the efficacy of covariance-based and variance-based SEM. International Journal of research in Marketing, 26(4), 332-344. https://doi.org/10.1016/j.ijresmar.2009.08.001

Rice, J. K. (2001). Explaining the negative impact of the transition from middle to high school on student performance in mathematics and science. Educational Administration Quarterly, 37(3), 372-400. https://doi.org/10.1177/00131610121969352

Rosário, P., Núñez, J. C., Valle, A., González-Pienda, J., \& Lourenço, A. (2013). Grade level, study time, and grade retention and their effects on motivation, self-regulated learning strategies, and mathematics achievement: a structural equation model. European journal of psychology of education, 28(4), 1311-1331. https://doi.org/10.1007/s10212-012-0167-9

Sarstedt, M., Ringle, C. M., \& Hair, J. F. (2017). Partial least squares structural equation modeling. In C. 
Homburg, M. Klarmann \& A. Vomberg (Eds.), Handbook of Market Research (pp. 1-40). Springer, Cham. https://doi.org/10.1007/978-3-319-05542-8_15-1

Schoenfeld, A. (1985). Mathematical Problem Solving.

Schommer, M. (1998). The role of adults' beliefs about knowledge in school, work, and everyday life. Adult learning and development: Perspectives from educational psychology, 127-143.

Schunk, D. H., \& Usher, E. L. (2011). Assessing self-efficacy for self-regulated learning. Handbook of self-regulation of learning and performance, 282-297. https://doi.org/10.4324/9780203839010

Shmueli, G., \& Koppius, O. R. (2011). Predictive analytics in information systems research. MIS quarterly, 553-572. https://doi.org/10.2307/23042796

Tall, D. (2002). The psychology of advanced mathematical thinking. In D. Tall (Ed.), Advanced mathematical thinking (pp. 3-21). Springer. https://doi.org/10.1007/0-306-47203-1_1

Wong, N.-Y., Ding, R., \& Zhang, Q. P. (2016). From classroom environment to conception of mathematics. In R. King \& A. Bernardo (Eds.), The psychology of Asian learners (pp. 541-557). Springer. https://doi.org/10.1007/978-981-287-576-1_33

Wood, L. N., Mather, G., Petocz, P., Reid, A., Engelbrecht, J., Harding, A., Houston, K., Smith, G. H., \& Perrett, G. (2012). University students' views of the role of mathematics in their future. International Journal of Science and Mathematics Education, 10(1), 99-119. https://doi.org/10.1007/s10763-011-9279-y

Wu, X. (2018). Persistence and Characteristics of Calculus I Students in STEM Disciplines.

Zimmerman, B. J., \& Schunk, D. (2011). Motivational sources and outcomes of self-regulated learning and performance. Handbook of self-regulation of learning and performance, 5(3), 49-64.

\section{Copyrights}

Copyright for this article is retained by the author(s), with first publication rights granted to the journal.

This is an open-access article distributed under the terms and conditions of the Creative Commons Attribution license (http://creativecommons.org/licenses/by/4.0/). 